\title{
The Influence of Leadership, Organization Behavior, Compensation, And Work Discipline on Employee Performance in Non-Production Departments PT. Team Metal Indonesia
}

\author{
Rejeki Bangun ${ }^{1 *}$, Sri Langgeng Ratnasari², Lukmanul Hakim³ \\ 1,2,3 Universitas Riau Kepulauan, Jl. Pahlawan No. 99, Bukit Tempayan, Batu Aji, Kota Batam, Provinsi Kepulauan Riau, Indonesia
}

${ }^{*}$ Corresponding author: rejeki@teammetal.com

\begin{abstract}
This research is to get information about leadership, organization behavior, compensation, work discipline and four factors to employee performance in Non-Production Department PT. Team Metal Indonesia. This research used a questionnaire for 94 respondents and used SPSS version 20. This research is quantitative research, statistics analysis. Multiple Linear Regression method with quantitative analysis. Based on SPSS data analysis, the researcher got the result Multiple Linear Regression analysis to leadership (X1) is 2.071 with significant 0.041 , organization behavior (X2) is 0.817 with significant 0.416 , compensation $(X 3)$ is -0.726 with significant 0.470 and work discipline $(\mathrm{X} 4)$ is 2.985 with significant number 0.004 . Result of the simultaneous test (F test) 8.083 . Conclusion for this research are first hypothesis leadership has influence to employee performance, second hypothesis organization behavior has influence on employee performance but not significant, third hypothesis compensation has influence to employee performance but not significant, fourth hypothesis work discipline has partial influence to employee performance and last hypothesis that these four variables (leadership, organization behavior, compensation, and work discipline) have simultaneous influence on employee performance.
\end{abstract}

Keywords: Leadership; Organization Behavior; Compensation; Work Disciple; Employee Performance

\section{Introduction}

The success of an organization is very dependent on employee performance therefore employee required to contribute their best to the organization. Performance is the result of work that is by the responsibilities and authority of both organizations, groups, and individuals.

Efforts to realize work discipline in an organization are greatly influenced by various factors including; organizational culture, leadership, compensation and so forth. Employees will always be required to provide good work results so that they can provide added value to the organization. Leadership always involves someone's effort to influence the behavior of a follower in a situation. Sources of influence can be obtained formally, namely occupying certain managerial positions in a company or organization because managerial positions are obtained from a formal system so that one can assume the role of a leader is a result of the managerial position he occupies in an organization. Various types of obstacles will be encountered by individual organizations to work well so that their performance received by organizations and communities who need it.

This research will explain the influence of leadership, organization behavior, compensation and work discipline on the performance of the Production Department at PT. Team Metal Indonesia.
Article Information:

Received: 5 Nov 2019

Revised: 15 Nov 2019

Accepted: 23 Nov 2019

DOI:

http://dx.doi.org/10.31580/jrp.v1i4.1116
Leadership is the ability of a leader to ensure his/her subordinates to be willing to collaborate to achieve organizational goals that have been set. The function of a leader is not only limited to coordination but covers all fields or aspects. If this leader can carry out the great responsibility and motivation of the subordinates, then the leader can be said as a successful leader.

Organization behavior is related to how organizational members understand the cultural characteristics of an organization. Organization behavior, in general, is a philosophical statement, can be used as a demand that binds the members of the organization because it can be formulated formally in various organizational rules and regulations.

Compensation is giving rewards to employees for the work they have done that will improve work performance, work motivation, and employee job satisfaction. Compensation is one tool used to lure individuals and groups, perform certain behaviors that are considered to improve organizational effectiveness.

Good discipline reflects a person's sense of responsibility for the tasks given to him/her. Therefore, every leader always strives for his/her subordinates to have good discipline. Because with discipline, the goals to be achieved can be more effective and efficient.

Research purposes 
1. To analyze the effect of leadership on the performance of NonProduction Department employees at PT. Team Metal Indonesia.

2. To analyze the effect of organizational behavior on the performance of Non-Production Department employees at PT. Team Metal Indonesia.

3. To analyze the effect of compensation on the performance of Non-Production Department employees at PT. Team Metal Indonesia.

4. To analyze the effect of work discipline on the performance of Non-Production Department employees at PT. Team Metal Indonesia

5. To analyze the effect of leadership, organization behavior, compensation, work discipline simultaneously on the performance of Non-Production Department employees at PT. Team Metal Indonesia.

\section{Literature review}

\section{Performance}

Performance is the achievement of works results or achievements and is one measurement of actual behavior in the workplace that is multidimensional (Mathis and Jackson, 2014).

\section{Leadership}

Leadership is behavior influencing subordinates in order to achieve organizational goals (Badeni, 2014).

\section{Organization Behavior}

Organization behavior as ability and willingness to one's behavior to organizational behavior and have high relevance to willingness, ability and willingness to increase work productivity, (Romli, 2014)

\section{Compensation}

Compensation is a way of personnel department to improve work performance, work motivation, and job satisfaction by giving everything in return for services to employees (Handoko, 2014).

\section{Work Discipline}

Discipline is the willingness of someone to follow all the rules of the company or organization and prevailing social norms (Hasibuan, 2013).

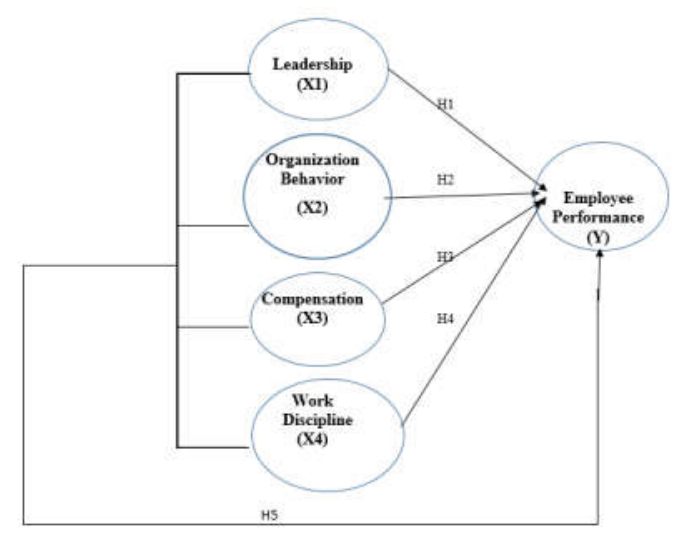

Fig. 1. Conceptual Framework
1. There is an influence of leadership on the performance of Non-Production Department employees at PT. Team Metal Indonesia.

2. There is an influence of organizational behavior on the performance of Non-Production Department employees at PT. Team Metal Indonesia.

3. There is an influence of compensation on the performance of Non-Production Department employees at PT. Team Metal Indonesia.

4. There is an influence of work discipline on the performance of Non-Production Department employees at PT. Team Metal Indonesia.

5. There are influences of leadership, organization behavior, compensation, and work discipline simultaneously on the performance of Non-Production Department employees at PT. Team Metal Indonesia.

\section{Methodology}

This research is quantitative research, which is designed to find and explain causal relationships between variables through hypothesis testing (explanatory research). According to Sugiyono (2013) hypothesis testing is research that aims to test hypotheses in general is a study that describes the phenomenon in the form of relationships between variables obtained based on data and facts that exist related to variables of Leadership, Organization Behavior, Compensation, Work Discipline also their influence on Employee Performance at PT. Team Metal Indonesia, with initial collection techniques namely initial observation, library research, and field research by distributing research instruments in the forms of questionnaires with Likert scale to a sample of 94 employees using SPSSVer 20 software of Non Production department PT. Team Metal Indonesia.

\section{Results}

Table 1: t-test results

\begin{tabular}{cccccc} 
& \multicolumn{2}{c}{$\begin{array}{c}\text { Unstandardized } \\
\text { Coefficients } \\
\text { Std. }\end{array}$} & $\begin{array}{c}\text { Standardized } \\
\text { Coefficients }\end{array}$ & $\mathrm{t}$ & Sig. \\
& $\mathrm{B}$ & Error & Beta & & \\
\hline (Constant) & 14.849 & 7.907 & & 1.878 & .064 \\
X1 & .204 & .098 & .230 & 2.071 & .041 \\
X2 & .150 & .184 & .090 & .817 & .416 \\
X3 & -.077 & .105 & -.076 & -.726 & .470 \\
X4 & .654 & .219 & .340 & 2.985 & .004 \\
\hline
\end{tabular}

Table 2: $\mathrm{F}$ test results

\begin{tabular}{llccccc}
\hline & & & & & & \\
& Model & Sum of & & Mean & & \\
& & Squares & df & Square & $\mathrm{F}$ & Sig. \\
\hline 1 & Regression & 756.254 & 4 & 189.063 & 8.083 & $.000^{\mathrm{b}}$ \\
& Residual & 2081.799 & 89 & 23.391 & & \\
& Total & 2838.053 & 93 & & & \\
& & & & & & \\
\hline
\end{tabular}

Research Hypothesis 


\section{Discussion}

Results of this research that all independent variables (leadership, organization behavior, compensation, and work discipline) had an influence on employee performance.

The following is a description of the analysis of research based on variables.

1. From the calculation, the significance value for the Leadership is 0.041 and the $t$ value of $2.071>\mathrm{t}$-table 1.99 . Thus the conclusion of the Leadership variable has influential to Employee Performance variables.

2. From the calculation, the significance value for the variable Organization behavior is 0.416 and t-count $0.817<\mathrm{t}$-table 1.99 then Ho is accepted or Ha is rejected. Thus the conclusions of the Organization behavior variables are influential but not significant to the Employee Performance variable.

3. From the calculation, the significance value for the Compensation variable is 0.470 and t-count $-0.726<\mathrm{t}$-table 1.99 then $\mathrm{Ho}$ is accepted or $\mathrm{Ha}$ is rejected. Thus the conclusion of the Compensation variable is influential but not significant to the Employee Performance variable.

4. From the calculation, the significance value for the Work Discipline variable is 0.004 and t-count 2.985> t-table 1.99 then Ho is rejected or Ha is accepted. Thus the conclusion of Work Discipline is influential on Employee Performance variables.

5. From the ANOVA test or F-test, the F count is 8.083 and with a probability of 0,000 . Probability is much smaller $(<)$ than 0.05 , so regression models can be used to predict performance. The SPSS output also shows p-value 0,000 $<0,05$ and F-count of $8083>$ F-table 2.48 , which means it is significant. Thus it concluded that the variables of Leadership, Organizational behavior, Compensation and Work Discipline simultaneous influence the Employee Performance.

\section{Conclusion}

1. Partially leadership influence on the performance of nonproduction department employees at PT. Team Metal Indonesia. This means that appropriate leadership can improve the performance of employees of non-production department PT. Team Metal Indonesia. Supportive leadership becomes an appropriate leadership style in providing solutions to employees when faced with problems in their work. Improving leadership can have an impact on improving the performance of non-production department employees at PT. Team Metal Indonesia.This finding is in line with the findings of Huang et al (2011), Luthans(2016), Raf et al. (2014), Ratnasari, Sutjahjo, and Adam (2018).

2. Organization behavior has no effect on the performance of non-production department employees at PT. Team Metal Indonesia. The current organizational culture is a culture of honesty and a desire to learn the tasks given by the company. The culture of openness and culture of doing work efficiently has not become a culture in the non-production department of PT. Team Metal Indonesia. The current increase in organizational culture can cause a decrease in employee performance related to the culture of openness and culture of doing work efficiently which has not been maximized.This result is in line with Allard (2010) and Aripin et al. (2013).

3. Compensation has no effect on the performance of nonproduction department employees at PT. Team Metal Indonesia. The current compensation is only in the form of treatment for employees in accordance with current health costs. Compensation is in incentives and salaries provided are also not in accordance with the workload that is carried out by employees. Current compensation increases can cause a decrease in employee performance related to incentives and salaries.This finding not in line with the findingsMusriha (2009), Condlyat al (2008).

4. Partially work discipline has influence on the performance of employees of non-production department PT. Team Metal Indonesia. This means that good work discipline can improve the performance of employees of non-production department PT. Team Metal Indonesia. Coming on time to the workplace and obeying the applicable regulations can improve employee performance. Improving discipline can have an impact on improving the performance of non-production department employees at PT. Team Metal Indonesia. This finding is in line with the finding of Dunggio (2013).

5. Simultaneously the influence given by the four independent variables is positive, meaning that the better (high) leadership, organizational culture, compensation, and work discipline will result in the better (higher) performance of the employees produced. This finding is in line with the finding on Dunggio (2013), Aulia, R. (2014).

\section{References}

Allard, I.N. (2010), Examining Relationship between Organizational Culture and Performance: Moderators of Culture Gap, Northcentral University, Prescott Valley, Arizona.

Aripin, Salim, U., Setiawan, M. and Djumahir (2013),"Implications of organizational culture and leadership styles: the effects on job satisfaction and organizational performance of police sector in Bandung, Cimahi, Garut-west java", IOSR Journal of Business and Management, Vol. 7 No. 5, pp. 44-49

Aulia, R. (2014). Pengaruh Pendidikan dan Pelatihan, Kepuasan Kerja, Kepemimpinan terhadap Kinerja Perawat Rawat Inap RSUD Kabupaten Siak (The impact of education and training, satisfaction and leadership on employees' performance of RSUD Kabupaten Siak). Jurnal Tepak Manajemen Bisnis, 6(2), 63-72

Badeni. 2014. Manajemen Sumber Daya Manusia, Jakarta: Rineka Cipta

Condly, C., \& Stolovitch. (2008). The Effects of Incentives on Workplace Performance: A Meta-Analytic Review of Research Studies1. Performance Improvement Quarterly, 16(3), 46-63

Dunggio, M. (2013). Semangat dan disiplin kerja terhadap produktivitas kerja karyawan pada PT. Jasa Raharja (Persero) Cabang Sulawesi Utara [Spirit and work discipline on employees' productivity in the Jasa Raharja Sulawesi Utara Branch]. Jurnal EMBA, 1(4), 523-533.

Handoko T, Hani. 2014. Manajemen Personalia dan Sumber Daya Manusia. Yogyakarta: BPFE-Yogyakarta.

Hasibuan, Malayu. 2013. Manajemen Sumber Daya Manusia, Jakarta: PT Bumi Aksara.

Huang, C.-M., Hsu, P.-Y. and Chiau, W.-L. (2011), "Perceptions of the impact of chief executive leadership style on organizational performance through successful enterprise resource planning", Social Behavior and Personality: An International Journal, Vol. 39 No. 7, pp. 865-878.

Luthans, F. (2016). Organizational Behavior (VivinAndhikaYuwono (trans.), ShekarPurwanti, Th. Arie P, and WinongRosari). Yogyakarta: Andi.

Mathis, Robert L dan John H. Jackson. 2014. ManajemenSumberDayaManusia. Buku 1, AlihBahasa: Jimmy SadelidanBayu. PrawiraHie, Jakarta: SalembaEmpat.

Musriha. (2009). Effect of motivation, training and compensation to employee performance in the service industry and trade Probolinggo district. Dialectics Journal, 6(1)

Ratnasari, Sri Langgeng., Gandhi Sutjahjo, and Adam. (2018). Lecturer's Performance: Leadership, Organizational Culture, Work Motivation, and Work Behavior. International Conference of Organizational Innovation (ICOI 2018). KnE Social Sciences.

Romli, Khomsyahrial. 2014. Komunikasi Organisasi Lengkap. Grasindo. Jakarta

Sugiyono. 2013. Metode Penelitian Kuantitatif, Kualitatif dan R\&D. Bandung:CV. Alfabeta. 


\section{Appendix}

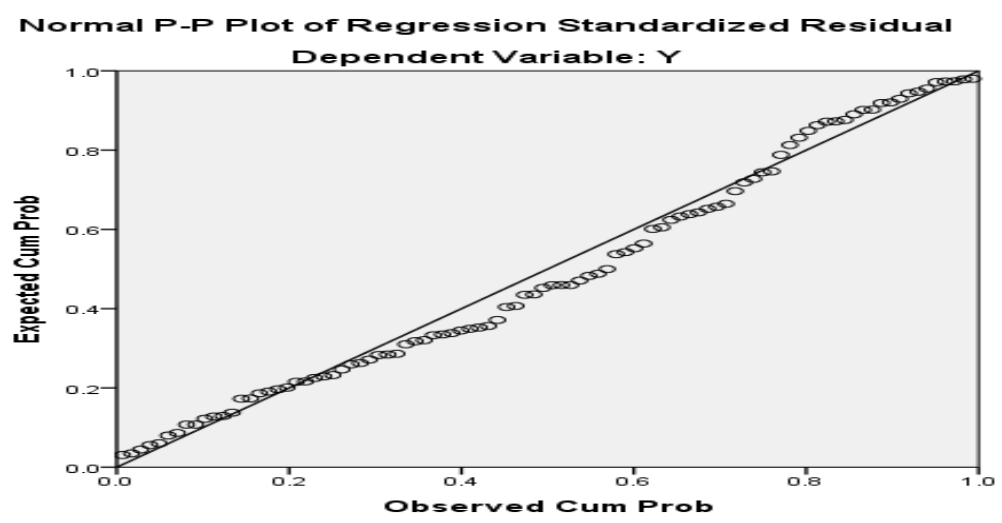

Fig. 2. Normality test

\begin{tabular}{|c|c|c|c|c|c|c|c|c|}
\hline & \multirow[t]{2}{*}{ Model } & \multicolumn{2}{|c|}{ Unstandardized Coefficients } & \multicolumn{3}{|l|}{$\begin{array}{l}\text { Standardized } \\
\text { Coefficients }\end{array}$} & \multicolumn{2}{|c|}{ Collinearity Statistics } \\
\hline & & B & Std. Error & Beta & $\mathrm{t}$ & Sig. & Tolerance & VIF \\
\hline 1 & (Constant) & 14.849 & 7.907 & & 1.878 & .064 & & \\
\hline & $\mathrm{X} 1$ & .204 & .098 & .230 & 2.071 & .041 & .671 & 1.491 \\
\hline & $\mathrm{X} 2$ & .150 & .184 & .090 & .817 & .416 & .676 & 1.480 \\
\hline & $\mathrm{X} 3$ & -.077 & .105 & -.076 & -.726 & .470 & .758 & 1.320 \\
\hline & $\mathrm{X} 4$ & .654 & .219 & .340 & 2.985 & .004 & .635 & 1.575 \\
\hline
\end{tabular}

a. Dependent Variable: $\mathrm{Y}$

Table $2: \mathrm{F}$ test

\begin{tabular}{llccccc}
\hline \multicolumn{1}{c}{ Model } & $\begin{array}{c}\text { Sum of } \\
\text { Squares }\end{array}$ & df & Mean Square & F & Sig. \\
\hline $1 \quad$ Regression & 756.254 & 4 & 189.063 & 8.083 & $.000^{\mathrm{b}}$ \\
& Residual & 2081.799 & 89 & 23.391 & & \\
\multirow{2}{*}{ Total } & 2838.053 & 93 & & & \\
\hline
\end{tabular}

Table 3 : R square result

\begin{tabular}{|c|c|c|c|c|c|c|c|c|c|c|}
\hline \multicolumn{11}{|c|}{ Model Summary ${ }^{\mathbf{b}}$} \\
\hline & & & & & & & & Statist & & \\
\hline $\begin{array}{l}\text { Model } \\
1\end{array}$ & $\mathrm{R}$ & $.516^{\mathrm{a}}$ & $\begin{array}{r}\text { R Square } \\
.266\end{array}$ & $\begin{array}{r}\text { Adjusted } \\
\text { R Square } \\
.234\end{array}$ & $\begin{array}{l}\text { Std. Error of the } \\
\text { Estimate } \\
4.836\end{array}$ & $\begin{array}{r}\text { R Square } \\
\text { Change } \\
.266\end{array}$ & $\begin{array}{r}\text { F Change } \\
8.083\end{array}$ & $\begin{array}{ll}\text { df1 } & \\
& \end{array}$ & df2 & $\begin{array}{l}\text { Sig. F } \\
\text { Change } \\
.000\end{array}$ \\
\hline
\end{tabular}

